\title{
Intereference of storage temperatures in the development of mesophilic, psychrotrophic, lipolytic and proteolytic microbiota of raw milk
}

\section{Interferência de temperaturas de estocagem no desenvolvimento da microbiota mesófila, psicrotrófica, lipolítica e proteolítica de leite cru}

\author{
Luana Martins Perin ${ }^{1}$; Paula Mendonça Moraes ${ }^{1}$; \\ Michelle Vieira Almeida ${ }^{1}$; Luís Augusto Nero ${ }^{2 *}$
}

\begin{abstract}
With the objective of comparing distinct storage conditions of raw milk, 20 samples of raw milk were collected, and portions of each were stored at different storage conditions $\left(4^{\circ} \mathrm{C}\right.$ for $48 \mathrm{~h}, 7^{\circ} \mathrm{C}$ for $48 \mathrm{~h}$ and $25^{\circ} \mathrm{C}$ for $4 \mathrm{~h}$ ). Populations of mesophilic aerobes and psychrotrophics (total, lipolytic and proteolytic) were monitored, and the results were compared by analysis of variance (ANOVA, $\mathrm{P}<0.05$ ). Psychrotrophics were randomly selected and identified. Mesophilic aerobes had significant development after $48 \mathrm{~h}$ at $7^{\circ} \mathrm{C}$ and $25^{\circ} \mathrm{C}$. For psychrotrophics, the differences were evident in samples with high levels of initial contamination. Pseudomonas and Serratia were the main species of contamination. The storage conditions of raw milk allowed the development of spoilage psychrotrophics, which were more evident in samples with low microbiological quality.
\end{abstract}

Key words: Milk storage, raw milk, microbiological quality, psychrotrophic

\section{Resumo}

Com o objetivo de comparar a contagem microbiana do leite cru em distintas condições de armazenamento, 20 amostras foram coletadas e alíquotas armazenadas em diferentes condições $\left(4^{\circ} \mathrm{C}\right.$ por $48 \mathrm{~h}, 7^{\circ} \mathrm{C}$ por 48 horas e $25^{\circ} \mathrm{C}$ por $4 \mathrm{~h}$ ). As populações de microrganismos aeróbios mesófilos e psicrotróficos (total, lipolíticos e proteolíticos) foram monitoradas e os resultados foram comparados pela análise de variância (ANOVA, $\mathrm{P}<0,05$ ). Psicrotróficos foram selecionados aleatoriamente e identificados. Aeróbios mesófilos tiveram desenvolvimento significativo após $48 \mathrm{~h}$ em $7^{\circ} \mathrm{C} \mathrm{e} 25^{\circ} \mathrm{C}$. Para psicrotróficos, as diferenças foram evidentes em amostras com elevados níveis de contaminação inicial. Pseudomonas e Serratia foram as principais espécies identificadas. Considerando os resultados obtidos, as condições de armazenamento avaliadas permitiram o desenvolvimento de psicrotróficos, que foram mais evidentes em amostras com baixa qualidade microbiológica inicial.

Palavras-chave: Armazenamento do leite, leite cru, qualidade microbiológica, psicrotróficos

\footnotetext{
${ }^{1}$ Discentes do Programa de Pós-Graduação em Medicina Veterinária, Dept ${ }^{\circ}$ de Veterinária, Universidade Federal de Viçosa, Viçosa, MG. E-mail: 1-perin@hotmail.com; paula-mmoraes@hotmail.com; michellevieiramva@gmail.com

${ }^{2}$ Prof. do Dept ${ }^{\mathrm{o}}$ de Veterinária da UFV, Viçosa, MG. E-mail: nero@ufv.br

* Autor para correspondência
} 


\section{Introduction}

Main agents of fluid milk spoilage are the microorganisms that naturally compose the microbiota of milk, which during their development produce several substances that degrade milk components, such as lactose, protein and fat (CHAMBERS, 2007). The main method to control microbial growth is refrigerating raw milk from the early stages of production, thus controlling the product spoilage (BONFOH et al., 2003; PINTO; MARTINS; VANETTI, 2006). The ideal temperature for stocking raw milk is $4^{\circ} \mathrm{C}$, when the development of its microbiota is properly controlled (CHAMBERS, 2002; JAY; LOESSNER; GOLDEN, 2005).

Different countries and regions establish distinct storage methods of raw milk according to the characteristics of dairy farms and significance of dairy products in their economy (Table 1). Refrigeration of raw milk is the most common practice for its conservation, and different cooling temperatures that are considered suitable for storage are proposed. However, a tolerance of delivering raw milk in dairy industries at ambient temperature is observed because the refrigeration time of two to three hours after milking is respected. Furthermore, several countries establish specific microbiological criteria that must be followed independently of the adopted storage method (Table 1).

Considering that the storage conditions cause a change in the milk microbiota, inadequate refrigeration allows for the development of a specific group of microorganisms called psychrotrophics (GUINOT-THOMAS; AMMOURY; LAURENT, 1995, CELESTINO; IYER; ROGINSKI, 1997; SØRHAUG; STEPANIAK, 1997; PINTO; MARTINS; VANETTI, 2006). These microorganisms grow well at or below $7^{\circ} \mathrm{C}$, and their optimal growth temperatures are between $20^{\circ} \mathrm{C}$ and $30^{\circ} \mathrm{C}$ (JAY; LOESSNER; GOLDEN, 2005). The psychrotrophics are Gram-positive and Gram- negative microorganisms of several genera (SHAH, 1994; MUNSCH-ALATOSSAVA; ALATOSSAVA, 2006). Many of these microorganisms are sensitive to the pasteurisation temperature, but some species are able to produce heat-stable lipolytic and proteolytic enzymes (CHEN; DANIEL; COOLBEAR, 2003; KELLY; FLAHERTY; FOX, 2006), which are considered to be the main spoilage factors of milk and dairy products associated with this group (CELESTINO; IYER; ROGINSKI, 1997; CHEN; DANIEL; COOLBEAR, 2003; LEITNER et al., 2008; MARCHAND et al., 2008).

The objective of this work was to compare different storage conditions of raw milk with consideration of their effects on different populations of hygiene indicator microorganisms. Furthermore, the predominant psychrotrophic microbiota in each refrigeration method was characterised at the species level.

\section{Material and Methods}

\section{Sample collection, storage and dilution}

Raw milk samples (approximately $300 \mathrm{~mL}$ ) from 20 dairy farms were collected directly from milk cans or bulk tanks and stored at $4{ }^{\circ} \mathrm{C}$ for a maximum 2 hours until analysis. In aseptic conditions, all samples were divided into $100 \mathrm{ml}$ aliquots, stored in sterile flasks and maintained in different storage conditions as follows: 1) $4^{\circ} \mathrm{C}$ for $\left.48 \mathrm{~h}, 2\right) 7^{\circ} \mathrm{C}$ for 48 $\mathrm{h}$, and 3) $25^{\circ} \mathrm{C}$ (simulating ambient temperature) for $4 \mathrm{~h}$. The tested storage conditions were established according to the distinct requirements for raw milk adopted in different countries and regions (Table 1). From each sample, $10 \mathrm{~mL}$ were collected before storage at time $(\mathrm{T})=0 \mathrm{~h}$, after $2 \mathrm{~h}$ and $4 \mathrm{~h}$ (aliquots were maintained at $25^{\circ} \mathrm{C}$ ) and after $24 \mathrm{~h}$ and $48 \mathrm{~h}$ (aliquots were maintained at $4^{\circ} \mathrm{C}$ and $7^{\circ} \mathrm{C}$ ). After the collection, the aliquots were diluted ten-fold with $0.85 \%$ sodium chloride $(\mathrm{NaCl})$ and submitted for microbiological analyses. 


\section{Microbiological analyses}

Mesophilic aerobes were enumerated in selected dilutions of each sample using Petrifilm ${ }^{\mathrm{TM}}$ AC plates (3M Microbiology, St. Paul, MN, USA) incubated at $35^{\circ} \mathrm{C}$ for $48 \mathrm{~h}$. Psychrotrophics were enumerated using Plate Count Agar (PCA; Oxoid Ltd., Basingstoke, Hampshire, England) with duplicate surface spreading and an incubation at $7^{\circ} \mathrm{C}$ for ten days (DOWNES; ITO, 2001). Lipolytic and proteolytic psychrotrophics were enumerated using PCA added to $1 \%$ tributyrin (Sigma-Aldrich, St. Louis, MO, USA) and 10\% skimmed milk (Molico, Nestlé, São Paulo, Brazil), respectively, with duplicate surface spreading and an incubation at $7^{\circ} \mathrm{C}$ for ten days (DOWNES; ITO, 2001). After incubation, formed colonies were enumerated. Only colonies that had inhibition halos were considered lipolytic and proteolytic psychrotrophics. All results were expressed in colony forming units per millilitre (cfu/ml).

\section{Identification of lipolytic and proteolytic} psychrotrophic microorganisms

After enumeration, 192 isolated cultures of lipolytic and proteolytic psychrotrophics were randomly selected and purified in 5\% sheep blood agar (incubation at $35^{\circ} \mathrm{C}$ for $24 \mathrm{~h}$ to $48 \mathrm{~h}$ ). Isolated colonies of each culture were characterised according to morphology and Gram staining. Gramnegative rods were characterised according to oxidase production, and 80 cultures were selected for biochemical identification using Bactray kits (Laborclin Ltda, Curitiba, PR, Brazil) and API20E (bioMérieux, Sigma, France).

\section{Statistical analyses}

The obtained counts for each group of microorganisms were converted to $\log _{10}$, and the means were compared by ANOVA considering the different storage conditions to identify significant differences $(\mathrm{P}<0.05)$. Additionally, samples were grouped according to counts of mesophilic aerobes obtained in $\mathrm{T}=0 \mathrm{~h}$ (higher or lower than $5 \log \mathrm{cfu} /$ $\mathrm{ml}$ ), and the obtained mean values compared by ANOVA $(\mathrm{P}<0.05)$. All analyses were performed using the Statistics 7.0 software (StatSoft, Tulsa, OK, USA).

\section{Results and Discussion}

The mean values for each group of microorganisms according to distinct levels of mesophilic aerobes contamination at $\mathrm{T}=0 \mathrm{~h}$ are detailed in Table 2. The development of the microbiota in samples with distinct levels of initial mesophilic contamination (higher and lower than 5 $\log \mathrm{cfu} / \mathrm{ml}$ ) is illustrated in Figure 1. Considering the obtained counts in $\mathrm{T}=0 \mathrm{~h}$ as a reference, distinct behaviours of the hygiene indicator microorganisms were observed according to each storage condition. For mesophilic aerobes significant differences were observed after $48 \mathrm{~h}$ of storage at $7^{\circ} \mathrm{C}$ and after $2 \mathrm{~h}$ and $4 \mathrm{~h}$ of storage at $25^{\circ} \mathrm{C}$. These differences were more frequent in samples with an initial mesophilic contamination that was higher than $5 \log \mathrm{cfu} / \mathrm{ml}$ (Figure 1). These results indicated that for this group of microorganisms, storage conditions at low temperatures (Table 2) were adequate to maintain the microbiological quality of raw milk when the initial contamination was properly controlled (TAVARIA; REIS; MALCATA, 2006; PINTO; MARTINS; VANETTI, 2006; NERO; VIÇOSA; PEREIRA, 2009). However, the maintenance of raw milk at $25^{\circ} \mathrm{C}$, which was similar to ambient temperatures, was not sufficient to control the microbiological development (Table 2). 
Figure 1. Mean counts of hygiene-indicator microorganisms on milk samples stored in different conditions $\left(\bullet: 25^{\circ} \mathrm{C}\right.$, $\left.\square: 4^{\circ} \mathrm{C} ; \Delta: 7^{\circ} \mathrm{C}\right)$. mesophilic aerobes: graphics $\mathrm{A}$ and $\mathrm{B}$; Psychrotrophics: graphics $\mathrm{C}$ and $\mathrm{D}$; Lipolytic psychrotrophics: graphics E and F; Proteolytic psychrotrophics: graphics G and H. Samples with initial aerobic mesophiles counts lower (left side) and higher (right side) than $5 \log \mathrm{cfu} / \mathrm{ml}$.

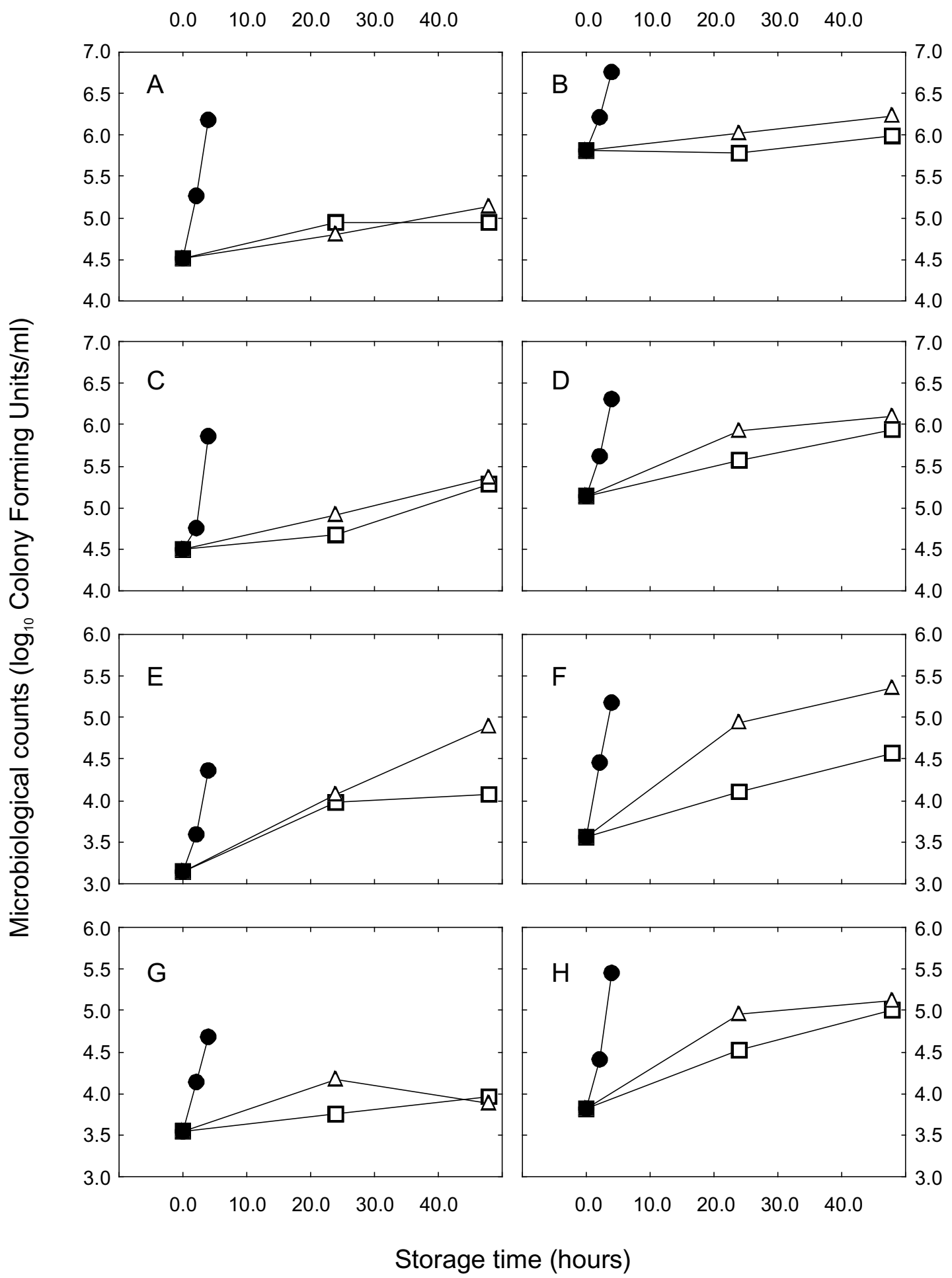

Source: Elaboration of the authors. 
Table 1. Raw milk storage requirements and microbiological criteria adopted in selected countries and regions according their official rules. Note from authors at the end of the manuscript.

\begin{tabular}{|c|c|c|c|}
\hline Country/Region & Storage conditions & Microbiological criteria & Reference \\
\hline Argentina & $5^{\circ} \mathrm{C}$ or lower & $200,000 \mathrm{cfu} / \mathrm{ml}$ of MA & $\begin{array}{l}\text { ARGENTINA, } \\
1969\end{array}$ \\
\hline Brazil & $\begin{array}{l}4^{\circ} \mathrm{C} \text { to } 7^{\circ} \mathrm{C}-\text { bulk tank } \\
7^{\circ} \mathrm{C}-\text { milk cans immersed on } \\
\text { cooled water } \\
\text { Ambient temperature ( } 2 \text { hours } \\
\text { after milking) }\end{array}$ & $\begin{array}{l}750,000 \mathrm{cfu} / \mathrm{ml} \text { of MA (until 2011-2012) } \\
100,000 \mathrm{cfu} / \mathrm{ml} \text { of MA (after 2011-2012) }\end{array}$ & BRASIL, 2002 \\
\hline Canadá & 1 to $4^{\circ} \mathrm{C}$ & $50,000 \mathrm{cfu} / \mathrm{ml}$ of MA & CANADA, 1997 \\
\hline Colombia & $4 \pm 2^{\circ} \mathrm{C}$ & $700,000 \mathrm{cfu} / \mathrm{ml}$ of $\mathrm{MA}$ & COLOMBIA, 2006 \\
\hline Equador & No specifications & No specifications & EQUADOR, 2003 \\
\hline Europe & $\begin{array}{l}8^{\circ} \mathrm{C}-\text { daily collection } \\
6^{\circ} \mathrm{C}-\text { not daily collection } \\
\text { Ambient temperature }(2 \text { hours } \\
\text { after milking) }\end{array}$ & $100,000 \mathrm{cfu} / \mathrm{ml}$ of $\mathrm{MA}$ & $\begin{array}{l}\text { EUROPEAN } \\
\text { COMMISSION, } \\
2004\end{array}$ \\
\hline Mexico & $5^{\circ} \mathrm{C}$ or lower & $\begin{array}{l}\text { Minimum of } 120 \text { minutes in the } \\
\text { methylene blue reduction test }\end{array}$ & MEXICO, 2007 \\
\hline New Zealand & $\begin{array}{l}7^{\circ} \mathrm{C} \\
\text { Ambient temperature (3 hours } \\
\text { after milking) }\end{array}$ & $100,000 \mathrm{cfu} / \mathrm{ml}$ of MA & $\begin{array}{l}\text { NEW ZEALAND, } \\
2006\end{array}$ \\
\hline USA & $\begin{array}{l}4.4^{\circ} \mathrm{C} \text { until } 3 \text { hours after } \\
\text { milking } \\
10^{\circ} \mathrm{C} \text { until collecting } \\
\text { Ambient temperature ( } 2 \text { hours } \\
\text { after milking) }\end{array}$ & $100,000 \mathrm{cfu} / \mathrm{ml}$ of MA & USDA, 2010 \\
\hline
\end{tabular}

$\mathrm{MA}=$ mesophilic aerobes and $\mathrm{cfu} / \mathrm{ml}=$ colony forming units $/ \mathrm{ml}$.

Considering the group of psychrotrophics (Table 2), significant differences $(\mathrm{P}<0.05)$ were found in several conditions. For all samples, the mean number of psychrotrophics were significantly different from the mean number obtained at $\mathrm{T}=$ $0 \mathrm{~h}$ after storage at $4^{\circ} \mathrm{C}(48 \mathrm{~h}), 7^{\circ} \mathrm{C}(24 \mathrm{~h}$ and 48 $\mathrm{h})$, and $25^{\circ} \mathrm{C}(4 \mathrm{~h})$ indicating that these storage conditions allow significant development of this group and may even compromise the milk quality (CELESTINO; IYER; ROGINSKI, 1997; GUINOT-THOMAS; AMMOURY; LAURENT, 1995; MUNSCH-ALATOSSAVA; ALATOSSAVA, 2006; ARCURI et al., 2008; TEBALDI et al., 2008; NERO; VIÇOSA; PEREIRA, 2009). It was verified that the temperature of $7^{\circ} \mathrm{C}$ was not sufficient to maintain the initial population of the psychrotrophic microbiota indicating that the raw milk should be stored at $4^{\circ} \mathrm{C}$ up to $24 \mathrm{~h}$ after milking or maintained at ambient temperature for $2 \mathrm{~h}$ maximal in specific cases (Table 2). However, when the initial loads of mesophilic aerobes are higher than $5 \log \mathrm{cfu} / \mathrm{ml}$, the development of the psychrotrophic microbiota was significant even at $4^{\circ} \mathrm{C}$ after $24 \mathrm{~h}$ and at $25^{\circ} \mathrm{C}$ after $2 \mathrm{~h}$ (Figure 1). The microbiological quality of raw milk directly interferes in the composition of its psychrotrophic microbiota (CELESTINO; IYER; ROGINSKI, 1997), determining different behaviours according to storage conditions (MUNSCH-ALATOSSAVA; ALATOSSAVA, 2006). 
Analysing the groups of psychrotrophics in detail, lipolytics had significant development $(\mathrm{P}<0.05)$ at $4^{\circ} \mathrm{C}$ after $48 \mathrm{~h}, 7^{\circ} \mathrm{C}$ after $24 \mathrm{~h}$ and $48 \mathrm{~h}$ and $25^{\circ} \mathrm{C}$ after $2 \mathrm{~h}$ and $4 \mathrm{~h}$ (Table 2). Proteolytics, on the other hand, had significant development $(\mathrm{P}<0.05)$ in all storage conditions analysed (Table 2). These results show different behaviours of the psychrotrophic microbiota during development in different storage conditions (MUNSCH-ALATOSSAVA; ALATOSSAVA, 2006) despite their constitution being similar to the morphology of cultures with the predominance of Gram-negative rods (75\% of tested cultures, Table 3 ). Considering the different conditions, the storage at $7^{\circ} \mathrm{C}$ allowed a significant development of the lipolytics and proteolytics indicating that this temperature is inadequate for the proper conservation of raw milk.

Despite being considered adequate to control the development of mesophilic aerobes and total coliforms, the tested storage conditions allowed the development of psychrotrophics (total, lipolytics and proteolytics) in several situations, even at $4^{\circ} \mathrm{C}$ after $24 \mathrm{~h}$ and $48 \mathrm{~h}$. These results indicate the necessity for other evaluations of additional microbiological indicators as references for raw milk quality when low temperatures are used for storage of this product. The development of microbiological indicators was evident when the initial levels of mesophilic aerobes were higher than the established parameters (Table 1) indicating the significance of proper practices during milking and storage to improve raw milk quality.

Gram-negative bacteria are the contaminants most frequently found in refrigerated raw milk, as observed in this study and other studies (SHAH, 1994; ENEROTH et al., 1998). After biochemical identification, a predominance of Pseudomonas spp., Serratia spp., Acinetobacter spp. and Citrobacter spp. was found (Table 4), which are genera usually found in raw milk and associated with the production of proteases and lipases (MUNSCHALATOSSAVA; ALATOSSAVA, 2006). Lipolytic and proteolytic activity of the microbiota of raw 
milk depends directly on the storage conditions of this product in addition to the species, optimal $\mathrm{pH}$ and enzyme specificity (MUNSCH-ALATOSSAVA;
ALATOSSAVA, 2006). Considering the observed genera diversity, this variation in the metabolism may explain the different behaviours observed in samples with low initial microbiological quality.

Table 3. Results of morphology and Gram for 192 cultures of isolated lipolytic and proteolytic psychrotrophics of raw milk in different storage conditions.

\begin{tabular}{llllll}
\hline Storage & Morphology & \multicolumn{3}{c}{ Pipolytics } & \multicolumn{3}{c}{ Proteolytics } \\
\cline { 3 - 6 } & & $\mathrm{n}$ & $\%$ & $\mathrm{n}$ & $\%$ \\
\hline Control $(\mathrm{T}=0 \mathrm{~h})$ & Gram positive cocci & 2 & 10,5 & 7 & 38,9 \\
& Gram positive rods & 1 & 5,3 & 0 & 0,0 \\
& Gram negative rods & 16 & 84,2 & 11 & 61,1 \\
& & & & & \\
$4^{\circ} \mathrm{C}$ & Gram positive cocci & 3 & 15.8 & 5 & 25.0 \\
& Gram positive rods & 0 & 0.0 & 0 & 0.0 \\
& Gram negative rods & 16 & 84.2 & 15 & 75.0 \\
& Gram positive cocci & 7 & 35.0 & 7 & 36.8 \\
$7^{\circ} \mathrm{C}$ & Gram positive rods & 0 & 0.0 & 0 & 0.0 \\
& Gram negative rods & 13 & 65.0 & 12 & 63.2 \\
& Gram positive cocci & 9 & 23.7 & 8 & 20.5 \\
$25^{\circ} \mathrm{C}$ & Gram positive rods & 2 & 5.3 & 0 & 0.0 \\
& Gram negative rods & 27 & 71.1 & 31 & 79.5 \\
\hline
\end{tabular}

Table 4. Biochemical identification by Bactray and API 20E Kits of 80 cultures of isolated lipolytic and proteolytic psychrotrophics in raw milk in different storage conditions.

\begin{tabular}{|c|c|c|}
\hline Storage & Lipolytics & Proteolytics \\
\hline Control $(\mathrm{T}=0 \mathrm{~h})$ & $\begin{array}{l}\text { Enterobacter spp.; Acinobacter spp.; } \\
\text { Hafnia spp.; Pseudomonas spp. Serratia } \\
\text { spp. and Tatumella spp. }\end{array}$ & $\begin{array}{l}\text { Serratia spp.; Pseudomonas spp.; } \\
\text { Ochrobactrum spp.; Klebsiella spp.; } \\
\text { Stenotrophomonas spp. }\end{array}$ \\
\hline $4^{\circ} \mathrm{C}$ & $\begin{array}{l}\text { Aeromonas spp.; Citrobacter spp.; } \\
\text { Tatumella spp.; Ochrobactrum spp. }\end{array}$ & $\begin{array}{l}\text { Aeromonas spp.; Citrobacter spp.; Hafnia } \\
\text { spp.; Pseudomonas spp.; }\end{array}$ \\
\hline $7^{\circ} \mathrm{C}$ & $\begin{array}{l}\text { Acinobacter spp.; Citrobacter spp.; } \\
\text { Enterobacter spp.; Pseudomonas spp.; } \\
\text { Serratia spp.; Stenotrophomonas spp. }\end{array}$ & $\begin{array}{l}\text { Citrobacter spp.; Ochrobactrum spp.; } \\
\text { Pseudomonas spp.; Serratia spp. }\end{array}$ \\
\hline $25^{\circ} \mathrm{C}$ & $\begin{array}{l}\text { Citrobacter spp.; Escherichia spp.; } \\
\text { Klebsiella spp.; Pseudomonas spp.; } \\
\text { Serratia spp.; Tatumella spp. }\end{array}$ & $\begin{array}{l}\text { Citrobacter spp.; Enterobacter spp.; } \\
\text { Hafnia spp.; Pseudomonas spp.; Serratia } \\
\text { spp.; Tatumella spp. }\end{array}$ \\
\hline
\end{tabular}




\section{Conclusions}

The initial microbiological quality of raw milk had a direct influence on the development of spoilage microorganism groups in raw milk when subjected to different storage conditions. Considering that refrigeration at $4^{\circ} \mathrm{C}$ is ideal for raw milk storage, the development of mesophilic aerobes and total coliforms was properly controlled. However, when the initial contamination of raw milk was higher than reference parameters, distinct storage conditions were not sufficient to maintain the microbiological quality, especially of psychrotrophics. Thus, it is important that good production practices are followed by milk producers to obtain a product with higher microbiological quality that can be conserved in distinct storage conditions.

\section{Acknowledgments}

LA Nero is supported by CNPq and FAPEMIG. LM Perin is supported by CNPq, PM Moraes and MV Almeida are supported by CAPES.

\section{Note from the authors}

After acceptance of the paper, Instrução Normativa n. 62 was published in Brazil (Brasil, 2011) updating the deadlines for microbiological requirements in raw milk, published previously in Instrução Normativa n. 51 (Brasil, 2002). Based on this, the information concerning Brazil presented in Table 1 must be updated as follows:

\begin{tabular}{|c|c|c|c|}
\hline Country/region & Storage conditions & Microbiological criteria & Reference \\
\hline \multirow[t]{4}{*}{ Brazil } & $4^{\circ} \mathrm{C}$ to $7^{\circ} \mathrm{C}-$ bulk tank & $\begin{array}{l}750,000 \mathrm{cfu} / \mathrm{ml} \text { of MA (until } \\
2011-2012 \text { ) }\end{array}$ & BRASIL, 2011 \\
\hline & $\begin{array}{l}7^{\circ} \mathrm{C}-\text { milk cans immersed on } \\
\text { cooled water }\end{array}$ & $\begin{array}{l}600,000 \mathrm{cfu} / \mathrm{ml} \text { of MA (until } \\
2014-2015 \text { ) }\end{array}$ & \\
\hline & $\begin{array}{l}\text { Ambient temperature ( } 2 \text { hours } \\
\text { after milking) }\end{array}$ & $\begin{array}{l}300,000 \mathrm{cfu} / \mathrm{ml} \text { of MA (until } \\
2016-2017 \text { ) }\end{array}$ & \\
\hline & & $\begin{array}{l}100,000 \mathrm{cfu} / \mathrm{ml} \text { of MA (after } \\
2016-2017)\end{array}$ & \\
\hline
\end{tabular}

$\mathrm{MA}=$ mesophilic aerobes, and $\mathrm{cfu} / \mathrm{ml}=$ colony forming units $/ \mathrm{ml}$

\section{References}

ARCURI, E. F.; SILVA, P. D. L.; BRITO, M. A. V. P.; BRITO, J. R. F.; LANGE, C. C.; MAGALHÃES, M. M. A. Contagem, isolamento e caracterização de bactérias psicrotróficas contaminantes de leite cru refrigerado. Ciência Rural, Santa Maria, v. 38, n. 8, p. 2250-2255, 2008.

ARGENTINA. Ley 18284, 18 de julio de 1969. Codigo Alimentario Argentino. Capitulo VIII: alimentos lacteos, articulo 553 al 642. De la Canal y Asociados S.R.L., Buenos Aires, Argentina. 1969.
BONFOH, B.; WASEM, A.; TRAORE, A. N.; FANE, A.; SPILLMANN, H.; SIMBE, C. F.; ALFAROUKH, I. O.; NICOLET, J.; FARAH, Z.; ZINSSTAG, J. Microbiological quality of cow's milk taken at different intervals from the udder to the selling point in Bamako (Mali). Food Control, Reading, v. 14, n. 7, p. 495-500, 2003.

BRASIL. Instrução Normativa $n^{\circ}$ 51: Aprova os Regulamentos Técnicos de Produção, Identidade e Qualidade do Leite tipo A, do Leite tipo B, do Leite tipo C, do Leite Pasteurizado e do Leite Cru Refrigerado e o Regulamento Técnico da Coleta de Leite Cru Refrigerado e seu Transporte a Granel. Diário Oficial [da] União, Brasília, DF, 18 set. 2002. 
BRASIL. Instrução Normativa $\mathrm{n}^{\circ}$ 62: Regulamento Técnico de Produção, Identidade e Qualidade do Leite tipo A, o Regulamento Técnico de Identidade e Qualidade de Leite Cru Refrigerado, o Regulamento Técnico de Identidade e Qualidade de Leite Pasteurizado e o Regulamento Técnico da Coleta de Leite Cru Refrigerado e seu Transporte a Granel. Diário Oficial [da] União, Brasília, DF, 30 dez. 2011.

CANADA. National dairy code: production and processing regulations. Canadian food inspection system. Alberta, Canadá: Canadian Food Inspection Agency, 1997.

CELESTINO, E. L.; IYER, M.; ROGINSKI, H. The effects of refrigerated storage of raw milk on the quality of whole milk powder stored for different periods. International Dairy Journal, Edmonton, v. 7, n. 2/3, p. 119-127, 1997.

CHAMBERS, J. V. The microbiology of raw milk. In: ROBINSON, R. K. (Ed.). Dairy microbiology handbook. $3^{\text {rd }}$ ed. New York: Wiley-Interscience, 2002, p. 39-90.

CHEN, L.; DANIEL, R. M.; COOLBEAR, T. Detection and impact of protease and lipase activities in milk and milkpowders. International Dairy Journal, Edmonton, v. 13, n. 4, p. 255-275, 2003.

COLOMBIA. Ministerio de Protección Social de Colombia. Decreto Número 616. Regulamento técnico sobre los requisitos que debe cumplir la leche para consumo humano que se obtenga, procese, envase, transporte, comercializa, expenda, importe o exporte en el país. Diário Oficial [de] Colômbia. nº $^{\circ}$ 46.196, febrero de 2006. Bogota, Colombia, 2006.

DOWNES, F. P.; ITO, K. Compendium of methods for the microbiological examination of foods. 4. ed. Washington: American Public Health Association, 2001.

ENEROTH, A.; CHRISTIANSSON, A.; BRENDEHAUG, J.; MOLINA, G. Critical contamination sites in the production line of pasteurised milk, with reference to the psychrotrophic spoilage flora. International Dairy Journal, Edmonton, v. 8, n. 9, p. 829-834, 1998.

EQUADOR. Norma Técnica Equatoriana INEN 9. Leche cruda. Requisitos Tercera Revision. Registro Oficial $n^{o}$. 739 de 2003-01-07. Quito, Equador, 2003.

EUROPEAN COMMISSION. Regulation (EC) No. $853 / 2004$ of the European parliament and of the council of 29 April 2004. Laying down specific hygiene rules for food of animal origin. Official Journal of the European Union, L139, 2004. p. 55-205.
GUINOT-THOMAS, P.;AMMOURY, M.A.; LAURENT, F. Effects of storage conditions on the composition of raw milk. International Dairy Journal, Edmonton, v. 5, n. 2, p. 211-223, 1995.

JAY, J. M.; LOESSNER, M. J.; GOLDEN, D. A. Modern food microbiology. 7. ed. Gaithersburg: Aspen Publishers, 2005.

KELLY, A. L.; FLAHERTY, F. O.; FOX, P. F. Indigenous proteolytic enzymes in milk: a brief overview of the present state of knowledge. International Dairy Journal, Edmonton, v. 16, n. 6, p. 563-572, 2006.

LEITNER, G.; SILANIKOVE, N.; JACOBI, S.; WEISBLIT, L.; BERNSTEIN, S.; MERIN, U. The influence of storage on the farm and in dairy silos on milk quality for cheese production. International Dairy Journal, Edmonton, v. 18, n. 2, p. 109-113, 2008.

MARCHAND, S.; COUDIJZER, K.; HEYNDRICKX, M.; DEWETTINCK, K.; DE BLOCK, J. Selective determination of the heat-resistant proteolytic activity of bacterial origin in raw milk. International Dairy Journal, Edmonton, v. 18, n. 5, p. 514-519, 2008.

MEXICO. Norma Oficial Mexicana NOM-155SCFI-2003. Manual de normas de control de calidad de leche cruda. Liconsa, DP-02/2004, 2007. 28 p. Available at: <http://www.liconsa.gob.mx. $>$. Accessed at: 25 may. 2010.

MUNSCH-ALATOSSAVA, P.; ALATOSSAVA, T. Phenotypic characterization of raw milk-associated psychrotrophic bacteria. Microbiological Research, Copenhagen, v. 161, n. 4, p. 334-346, 2006.

NERO, L. A.; VIÇOSA, G. N.; PEREIRA, F. E. V. Qualidade microbiológica do leite determinada por características de produção. Ciência e Tecnologia de Alimentos, Campinas, v. 29, n. 2, p. 386-390, 2009.

NEW ZEALAND. Food safety authority. DPC 2: animal products (Dairy) Approved criteria for farm dairies. Ministry of Agriculture and Forestry. Wellington, New Zealand, 2006.

PINTO, C. L. O.; MARTINS, M. L.; VANETTI, M. C. D. Qualidade microbiológica de leite cru refrigerado e isolamento de bactérias psicrotróficas proteolíticas. Ciencia e Tecnologia de Alimentos, Campinas, v. 26, n. 3, p. 645-651, 2006.

SHAH, N. P. Psychrotrophs in milk: a review. Milchwissenschaft, Kempten, v. 49, n. 8, p. 432-437, 1994.

SØRHAUG, T.; STEPANIAK, L. Psychrotrophs and their enzymes in milk and dairy products: quality aspects. 
Trends in Food Science \& Technology, Colney, v. 8, n. 2, p. 35-40, 1997.

TAVARIA, F. K.; REIS, P. J. M.; MALCATA, F. X. Effect of dairy farm and milk refrigeration on microbiological and microstructural characteristics of matured Serra da Estrela cheese. International Dairy Journal, Edmonton, v. 16 , n. 8 , p. $895-902,2006$.
TEBALDI, V. M. R.; OLIVEIRA, T. L. C.; BOARI, C. A.; PICCOLI, R. H. Isolamento de coliformes, estafilococos e enterococos de leite cru provenientes de tanques de refrigeração por expansão comunitários: identificação, ação lipolítica e proteolítica. Ciência e Tecnologia de Alimentos, Campinas, v. 28, n. 3, p. 753-760, 2008.

USDA - United States Department of Agriculture. Milk for manufacturing purposes and its production and processing recommended requirements. Dairy Programs, 9. 2010. Available at: <http://www.ams.usda.gov/dairy/ manufmlk.pdf $>$. Accessed at: 25 may 2010. 